This article was downloaded by: [University of Stockholm]

On: 25 August 2011, At: 10:49

Publisher: Routledge

Informa Ltd Registered in England and Wales Registered Number: 1072954

Registered office: Mortimer House, 37-41 Mortimer Street, London W1T 3J H, UK

\title{
Identities
}

Publication details, including instructions for authors and subscription information:

http:// www.tandfonline.com/loi/gide20

\section{Putting Ecstasy to Work: Pleasure, Prostitution, and Inequality in the Indonesian Borderlands}

J ohan Lindquist ${ }^{\text {a }}$

a Department of Social Anthropology, Stockholm University, Stockholm, Sweden

Available online: 13 May 2010

To cite this article: J ohan Lindquist (2010): Putting Ecstasy to Work: Pleasure, Prostitution, and Inequality in the Indonesian Borderlands, Identities, 17:2-3, 280-303

To link to this article: http:// dx.doi.org/10.1080/10702891003733500

PLEASE SCROLL DOWN FOR ARTICLE

Full terms and conditions of use: http://www.tandfonline.com/page/termsand-conditions

This article may be used for research, teaching and private study purposes. Any substantial or systematic reproduction, re-distribution, re-selling, loan, sub-licensing, systematic supply or distribution in any form to anyone is expressly forbidden.

The publisher does not give any warranty express or implied or make any representation that the contents will be complete or accurate or up to date. The accuracy of any instructions, formulae and drug doses should be independently verified with primary sources. The publisher shall not be liable for any loss, actions, claims, proceedings, demand or costs or damages 
whatsoever or howsoever caused arising directly or indirectly in connection with or arising out of the use of this material. 


\title{
Putting Ecstasy to Work: Pleasure, Prostitution, and Inequality in the Indonesian Borderlands
}

\author{
Johan Lindquist \\ Department of Social Anthropology, Stockholm University, Stockholm, \\ Sweden
}

\begin{abstract}
This article takes the drug Ecstasy as a commodity located at the center rather than at the margins of social processes, a technology that allows for the temporary engagement with pleasure and displacement of inequality in the context of nightlife and prostitution. It addresses these issues by focusing ethnographic attention on how Indonesian female prostitutes and their Singaporean male clients use Ecstasy in a disco on the Indonesian island of Batam, an export-processing zone located at the border to Singapore. By paying close attention to consumption practices, the article uses Ecstasy as a starting point for illuminating intersections of social mobility and inequality in the context of contemporary forms of transnational capitalism.
\end{abstract}

Key Words: Drugs, globalization, prostitution, Indonesia, Singapore

It is Friday night and Andi is taking his weekly forty-minute ferry ride from the World Trade Center in Singapore across the border to the Indonesian island of Batam. It is 1999 and the Asian economic crisis is at its peak, taking victims along the way. Indonesia's President Suharto has been forced to resign, and the Indonesian rupiah has collapsed, falling to one-sixth of its previous value compared to the Singapore dollar. While formal investments have ground to a halt, the informal economy on Batam-based on drugs and prostitution-is booming. For some, crisis means bust; for others, it offers opportunity (cf. Tsing 2005: 42).

Since 1990, Batam and Singapore-together with the Malaysian province of Johor-have formed part of a transnational Growth Triangle. As Singapore was transformed from an export-processing zone for the global electronics industry into a knowledge-based financial center and global city, factories were increasingly moved to offshore sites of inexpensive land and labor, such as Batam, where local laws were changed to facilitate foreign direct investment. Since 1970, Batam's population has increased from 3,000 to approximately 700,000 ; most residents are impoverished pan-Indonesian migrants in 
search of work in the booming economy. Along with the factories, an economy based in the discos, karaoke bars, brothels, and gambling dens has developed. In this process, Batam has become one of the main points of tourist entry to Indonesia, as the number of arrivalsmost of them Singaporeans-has increased from 60,000 in 1985, to 580,000 in 1990, peaking at over 1.5 million by 2005 .

Andi has just gotten off work at one of Singapore's docks where he loads containers that will be shipped around the world. Upon arrival on Batam and after passing through immigration and customs, Andi is surrounded by touts, but in the crowd he quickly finds his usual taxi driver, who takes him straight to the main commercial settlement of Nagoya, where Sri, his Indonesian girlfriend, is waiting for him in the room he rents for her. After he showers they go out for dinner at one of the town's many food courts, packed with Singaporeans who have come to Batam for the weekend. Just before midnight Andi and Sri take a taxi to the island's largest disco, Ozon.

Along the busy road leading up to Ozon there are a series of small stalls that sell everything from noodle soup to cigarettes and condoms. At the top of the hill outside the club, the road is packed with taxis and motorcycle taxis (ojek) waiting for passengers who will pay exorbitant fares as they come stumbling out of the club. Passing the admissions booth, Andi and Sri are hit by a wall of sound as they enter the club. The air smells of clove cigarettes and air-conditioning. On a good night Ozon-Batam's most popular nightclub-is nearly filled to its capacity of 2,000 people by 11 p.m., and tonight this is certainly the case.

Lidya, an Indonesian woman in her early twenties, is standing at the bar looking around nervously. She is from North Sumatra and has been working on Batam as a freelance prostitute for more than a year. She is searching for a client-preferably a Singaporean. They tend to have more money and be more reliable than Indonesians. The Ecstasy-the popular term for MDMA (3,4-methylenedioxymethamphetamine, an amphetamine-type stimulant) - that she has taken has not quite taken effect, and she is indecisive about whom to approach. Unlike Lidya, who had a pill left over from the night before, Ani, who is standing nearby, doesn't have any drugs yet. She is looking for a client who will give her Ecstasy so that she can relax and focus on making money. She cannot afford to pay the 100,000 rupiah (about 10 United States dollars) that are necessary to buy it herself. Behind the disc jockey, and at the entrance to the toilets, young men sell drugs, mainly Ecstasy or marijuana, offering their goods to anyone who looks their way. Drugs can also be ordered directly from the waiters for a slightly higher price. 
At the back of the disco, the disc jockey is playing techno versions of Indonesian and Western songs, but only a few people are on the small dance floor in the middle of the club. In contrast, the high tables and bar stools that surround the dance floor are packed with people who can afford to buy drinks. Most of them are conspicuously moving their heads back and forth to the beat of the music-in most cases, such people are tripping on Ecstasy. Andi prefers to be somewhat more discreet and likes to sit behind the disc jockey, where he is hidden from view. Usually he asks Sri to buy the drug for him and they begin by splitting one pill between them. He doesn't approach the dealers himself. "I like for it to be placed in my hand so that I can just put it in my mouth."

On Batam, Andi experiences, as he puts it, "total enjoyment," which means "doing Ecstasy, listening to good music and having a woman," all of which would be more expensive and dangerous in Singapore. Batam, he says, "is like fantasy, Fantasy Island, while Singapore is like reality." In fact, traveling from Singapore to Batam is literally a passage from the "first" to the "third" world, as Singapore has been transformed from a "developing" into a "developed" country in the last two decades. Taking Ecstasy on Batam allows Andi to forget about the pressures of everyday life in Singapore and to avoid thinking about the future. "Ecstasy," he tells me, "clears my head of all the stress that I feel at home."

\section{The economy of the night}

Since the mid-1990s, Ecstasy has become the drug of choice in nightclubs on Batam and throughout Indonesia and Asia (Djaelani Gordon and Djaelani Gordon 2003: 364-365; Beazley 2008: 46-47; Field 2008: 25; Komlosy 2008: 62). Ecstasy is generally consumed in a type of place that is recognizable globally, namely, the disco, an environment that explicitly offers a variety of forms of "pleasures," most notably music, drugs, and sex. Arjun Appadurai (1996: 83-84) has argued that pleasure is the organizing principle and driving force in contemporary consumerism, and, more specifically, that an aesthetic of ephemerality drives this process. Few commodities are as concerned with the production of pleasure or as ephemeral as Ecstasy, with the positive effects of the drug rarely lasting more than six hours.

John, a Chinese Singaporean man who has managed nightclubs on Batam since the early 1990 s, has his own theory about the composition of people at the Ozon disco and how Ecstasy circulates there:

You can take nine people. Three will be Singaporeans looking for women. They book three women who are given Ecstasy; two of them take 
the drug and the third hands it over to a preman (a thug or gangster), who sells it to another person who just wants to be by himself. The final person is lost because he thinks he is at a regular disco.

John's comment suggests that we can understand the social organization of the disco in relation to the circulation of Ecstasy. It suggests that there is an economy at work. Ecstasy is the key element of this economy, yet differently situated actors engage differently with the drug: in Ozon, the drug is bought, given away, consumed, hidden, passed on, sold, and, for that "final person" in John's list, perhaps invisible.

In Ozon, Ecstasy is thus a commodity located at the center rather than at the margins of social processes. With this claim, I am not suggesting that the Ecstasy economy is comparable in monetary terms to that of the formal development projects on Batam, or even that of gambling, but rather that paying close attention to Ecstasy consumption and the Ozon disco offers insights into the creation of a particular transnational economy of pleasure that boomed in the years after the 1997 Asian economic crisis. As James Farrer (2008: 3-4) has noted, although nightlife is often dismissed as "play"-as opposed to "serious labor"-discos are in fact ideal spaces to consider the relationship between social mobility and subordination, particularly in developing countries such as China and Indonesia, where prostitution is prevalent. From this perspective, the disco becomes an ethnographic starting point from which to consider broader cultural, economic, and political transformations, and, through a concern with drug use in particular, the embodied tensions between pleasure and inequality in a globalizing world.

Other scholars have placed illicit drugs at the heart of political economic description and analysis. Carl Trocki (1990, 1999; see also Rush 1990), for instance, has argued that drugs should be considered as a critical actor in the economic history of the world and that opium in particular was the sine qua non of capitalist and colonial expansion in Asia during the nineteenth century, while anthropologist Philippe Bourgois-in his influential ethnography of the crack cocaine economy in New York's Spanish Harlem-claims that drug use is "the epiphenomenal expression of deeper, structural dilemmas" (1995: 319), most notably the racial and class divides that plague the United States.

But, while historians of opium in Southeast Asia have generally focused on the regulation of production and trade, this article takes consumption as its starting point. More critically-and in contrast to Bourgois-I argue that Ecstasy can be conceptualized as a technology that is constituitive of social relationships, ${ }^{1}$ rather than as strictly epiphenomenal and a symptom of political economy. Unlike opium, which is considered "primitive," and heroin, which is an isolationist 
drug, amphetamine-type stimulants such as Ecstasy are generally associated with mobility, modernity, and an entrepreneurial spirit throughout contemporary Asia (Lyttleton 2004). In China, Ecstasy had become "a staple of the Shanghai clubbing scene" by the late 1990s (Field 2008: 25) and was widespread in Kunming clubs by 2005 (Komlosy 2008: 62), as nightlife reemerged following two decades of market reform (Farrer 2008). In Indonesia, Ecstasy has become an important part of the electronic dance music scene in cosmopolitan areas such as Bali and Jakarta (Beazley 2008) and is widely used in karaoke bars and discos across the country. The behavior associated with Ecstasy use has become part of a broader cultural repertoire, as one frequently sees people moving their heads back and forth, simulating the experience of taking the drug. In a particularly memorable episode I witnessed, a young mother on Batam rocked her threemonth-old baby so that his head moved back and forth, and jokingly said that it looked like he was doing Ecstasy. Everyone present, including the grandmother, laughed together.

In the Ozon disco, John tells me, "the only reason people take Ecstasy is to feel good," while one clinical study claims that Ecstasy produces "an affective state of enhanced mood, well-being, and increased emotional sensitiveness, little anxiety, but no hallucinations or panic reactions" (Vollenweider et al. 1998: 241). John's statement and other pharmacological generalizations, however, obscure other processes that are at work in relation to the consumption and circulation of Ecstasy. In Ozon, Ecstasy produces not only pleasure, understood as a "harmonious state ... entirely contained within the subject" (Lenson 1995: 70), but individual actors who readily engage in other economic transactions, most notably the sale and purchase of sex. There are thus a range of investments in Ecstasy and in the pleasure it produces, as the drug lubricates a highly specific transnational economy. ${ }^{2}$ In other words, the experience of pleasure that the use of Ecstasy affords is not necessarily an end in itself; pleasure unfolds within existing social structures and affects these structures, producing effects beyond the context and temporality of the actual ecstasy use. The experience of drug use is thus structured in particular ways and depends on the social organization of spaces, interactions, habits, and norms. It follows that Ozon is a place that is being constructed within, not outside of, history.

\section{Beyond the borderless world}

During the 1980s, the "Pacific Rim" emerged as the economic region of the future; an area that would connect Asia with the United States 
(Dirlik 1993). Globalization became the key term of reference. As Japanese business guru Kenichi Ohmae (1995) put it, this was the era of a new "borderless world" in which the nation-state was becoming increasingly obsolete. People, goods, and capital were to flow freely, as "economic complementarity" and "comparative advantages" became the dominant tropes (Sparke et al. 2004: 486). In East and Southeast Asia, transborder and regional initiatives were planned and implemented in conjunction with this ethos.

In the early $1990 \mathrm{~s}$, regionalization took a particular idealized, geometrical form in Asia, as "Growth Triangles" embodied hopes for the future. The most successful of these were centered on the region's emerging global cities, Hong Kong and Singapore. As Hong Kong was incorporated into China, however, the Indonesia-Malaysia-Singapore Growth Triangle, which ideally connects Singapore, the Malaysian province of Johor, and Batam and several other islands in the Riau Archipelago, has become the most widely featured and discussed transnational economic project in East and Southeast Asia. ${ }^{3}$

At the center of the Growth Triangle project was the development of Batam, an island of small fishing villages that in the early 1970s was transformed into a major industrial project by the Indonesian national oil company Pertamina and then a site for multinational electronics factories in the 1990s. BJ Habibie, the head of the Batam Industrial Development Authority, and later president of Indonesia after the fall of Suharto, imagined that Batam, in direct competition with Singapore, would become the new "Houston" or later "Rotterdam" of Southeast Asia. Intensifying development led to major demographic and infrastructural changes as migrants from across Indonesia traveled to Batam in search of work in the booming economy, sometimes continuing further afield-most often undocumented-to Malaysia or Singapore.

Along with the construction of gated communities with names such as Palm Spring, there was a dramatic growth of squatter housing and of prostitution. In the 1970s prostitution catered primarily to Indonesian migrants and foreign workers, with the island's first brothel areas located in close geographical proximity to oil industry companies such as Pertamina and McDermott. By the 1990s, with the establishment of a regular ferry system and the growth of Singaporean and Malaysian tourism, prostitution diversified, as discos, hotels, karaoke bars, and gambling dens opened in Nagoya, thus creating the infrastructure for a sex industry that characterizes border regions throughout Asia and many other parts of the world. While low-charge brothel areas on Batam continued to cater primarily to Indonesian migrants, nightlife in the commercial areas increasingly focused on tourists from across 
the border. Similar developments were evident on nearby islands such as Bintan, Karimun, and Kundur, which all became directly accessible by ferry from Singapore (cf. Ford and Lyons 2008b: 177).

The expansion of prostitution intensified with the 1997 Asian economic crisis and the ensuing political crisis as the Indonesian rupiah collapsed in relation to the Singaporean dollar and Malaysian ringgit. While industrial development came to a halt, prostitution, gambling, and Ecstasy use-which had become prevalent on Batam only a few years earlier as it spread quickly throughout Asia-expanded dramatically with the increasing influx of tourists from Malaysia and Singapore in search of bargains and Indonesian migrants in search of work. Thus began the boom years of Batam's nightlife, as nearly one hundred karaoke bars, discos, and massage parlors opened in and around Nagoya.

Most of the ethnographic material in this article is based on research on Batam at the height of the boom, during thirteen months from 1998 to 1999, though I have made five further visits since. In more recent years, national processes of political decentralization have led to regional autonomy for the new Riau Island province, but, more importantly in the context of this article, there has been a national crackdown on gambling that has had major effects on Batam, as tourist arrivals from Singapore have dropped significantly. After the turn of the century drug raids have become increasingly common across Indonesia (cf. Beazley 2008: 46), but unlike in Singapore, the officially illegal drug is generally tolerated in Batam nightclubs and continues to be widely used. For understandable reasons, the extent of the drug economy has been and continues to be difficult to measure, but most local commentators I have talked with on Batam agree that access remains stable even if consumption has certainly dropped in real terms due to the downturn in tourism.

As Batam increasingly became identified with drug use and prostitution in the late 1990s, the Singaporean government attempted to control these transgressions by enforcing new techniques of surveillance at its borders. At the end of 1999, for instance, a conspicuous story on the front page of Singapore's major daily newspaper recounted how two young Singaporeans, who had been studying in Australia, were tested for drug use at Changi airport (Straits Times, 16 November 1999). Their urine samples showed traces of marijuana use during the previous month and both were sentenced to two years in prison.

In July 1998, the Misuse of Drugs Act was amended to allow the Central Narcotics Bureau (CNB) to charge Singaporeans and permanent residents who tested positive for drug use upon returning to the 
country. Previously, those who tested positive could only be referred to a clinic, but after the law was passed the maximum penalty was changed to ten years in prison and a 12,000 United States dollar fine. By November of the same year sixty people had been charged and twenty cases were pending. In 1999, 168 Singaporean citizens and permanent residents were arrested for using drugs overseas (Straits Times, 20 August 2000: 22). As the assistant director of the CNB put it at the time, "Those people who thought that they could get away with abusing drugs overseas have to think again" (Straits Times, 8 November 1998: 32). In similar terms, since the 1990s there have been frequent reports in the Singaporean press regarding Singaporeans taking second wives on Batam, with lifestyle magazines such as $\mathrm{Her}$ World (August 2004: 133) claiming that there are "virgins on sale" across the border, widespread perturbation concerning the Riau Archipelago as a source for the spread of HIV/AIDS to Singapore, and anxieties related to the practice of gambling. Furthermore, with the increasing demand for interventions against terrorism and piracy in Southeast Asia, there has been an increasing consolidation of crossborder mobility in the region.

Thus, although early commentators identified the Growth Triangle as an example of a post-national arena (e.g., Ohmae 1995), this particular transnational project has demanded not only the free flow of people and capital in one direction but also led to the increasing regulation of other forms of mobility as Singaporean capital and Indonesian labor were supposed to converge on Batam. In this context, it is not primarily businessmen moving comfortably in international space who are of interest, but rather the Indonesian migrants and Singaporean tourists who move within and between nation-states.

\section{Tripping}

Like Andi, whose story opened this article, Suleiman and Ibrahim, two Malay-Singaporean men in their mid-twenties, travel from Singapore to Batam nearly every Friday evening. Before leaving Singapore they page Agus, a taxi driver in his mid-twenties from Padang in West Sumatra, who is their chauffeur each time they come to Batam. Ibrahim claims that he has "become like a brother to us" and he accompanies them everywhere they go on Batam. "When the time is right," he says, "we plan to get him a passport so that he can come over and visit us in Singapore." Agus is waiting for them at the port in the car that he rents by the month and regularly uses as a taxi. He takes them straight to their usual hotel in Nagoya, where they shower, drink a few beers, and smoke some marijuana that Agus has 
bought for them. Suleiman has his portable CD-player with him and together they sit and listen to music as they talk and relax. They are both tired after having worked fifty-hour weeks.

Suleiman and Ibrahim grew up together in neighboring apartment blocks in Geylang, Singapore's predominant Malay area. Both graduated from high school, but neither had adequate grades or enough money in the family to go on to college or university. For the past few years Suleiman has worked in his uncle's plumbing business while Ibrahim has a job at a large multinational record store in the city's main shopping area, Orchard Road. They both avidly follow the latest clothing and music fashions, familiar not only in Singapore but also in Europe and the United States. But neither of them likes to talk about their lives in Singapore when they are on Batam, in part because they don't like their jobs, but more generally because they are unsure about what the future holds in store for them. "Enough!" says Ibrahim, when I ask him to elaborate on how he feels about living in Singapore. "Now we're here; let's just enjoy."

By 11 p.m. they are ready for the short drive up the hill to Ozon. Agus drops them at the door and as they wait for him to park and join them, they chat with the bouncer, who knows them by name. Once inside, a waiter takes them to their seats in a booth overlooking the dance floor, and within minutes another waiter, whom they know well from previous visits, comes up and tells them what kinds of Ecstasy are available. They order beer and Ecstasy and within a quarter of an hour of consumption the drug has taken effect and they start shaking their heads back and forth to the beat of the techno music. They smoke a marijuana cigarette to intensify the effect of the Ecstasy. Occasionally, they stop to say a few words to each other, have a drink, or go to the toilet, but most of the time they continue moving their heads to the beat until early morning.

Behind the booth and near the stairs leading to the ground floor, a door leads into a hallway with a series of private rooms that are rented by the hour, each with couches, coffee tables, and a karaoke system. These are VIP rooms where one can find men like Wen, the Singaporean Chinese manager of a Japanese electronics factory in the Batamindo Industrial Estate. Wen is in his late forties and has lived in a gated community on Batam for the past two years after moving from another factory in Malaysia owned by the same company. Together with two other Singaporean Chinese male friends who also work on Batam, and various other acquaintances, he is a frequent visitor to Batam's discos, but to protect his identity he goes by the name Kepiting Saus, or Crab Sauce, and spends his time in private karaoke rooms, where he wears dark sunglasses and sings his favorite Chinese pop songs. 
Wen is well educated, speaks perfect English, and has worked in several countries throughout Asia, but he knows that he will never make it much higher in the corporate hierarchy. On Batam he is the boss-both in the factory and the nightclub-that he has never been and will never become in Singapore or any other metropole. From what I can tell, he seems to have come to terms with this. He tells me that he takes Ecstasy once a week, but I guess that he does so more frequently. Unlike the other Singaporean men I have described, Wen has an excellent salary by Singaporean standards and good contacts with Batam's disco managers, who offer access to the best drugs available. Like the other men I have discussed, he tells me that he takes Ecstasy to relax and get rid of "stress," which Chua (1995: 236) has identified as a key metaphor in relation to anxieties concerning modernization in Singapore. "What is important," Wen says, "is to be disciplined and not let the drug control you."

While Wen has never taken Ecstasy in Singaporean nightclubs, Suleiman has done so on occasion, but he claims that the experience is different compared to Batam. Since the penalties for drug use are stiff in Singapore and because he suspects that there are police everywhere, he has to control his body so that no one can tell that he is taking ecstasy. Suleiman claims that "if you take drugs in Singapore and get into the music everyone will turn and look at you. There are police everywhere." The spectre of the state is present, affecting the bodily, phenomenological, and psychic experience of drug use.

The Indonesian state, however, appears to function differently. Although it is frequently suggested that undercover police officers (intel) frequent Ozon, what makes this space appear relatively safe to Indonesians and Singaporeans alike is that the primary interest of Indonesian state actors is to transform power into money, rather than law enforcement per se (cf. Barker 1999, chapter 4). As such, the state guarantees both the circulation of Ecstasy and its safe consumption within particular spaces. Managers I spoke with at discos on Batam reported a steady flow of government officials who show up to pick up their "envelopes" (amplop), while the frequent public display of police destroying confiscated drugs for the media was often viewed by the public with cynicism (Barker 1999: 224-226). Notably, increasing drug raids in recent years on Batam have generally been aimed at factories or warehouses rather than the actual spaces of consumption. Similarly, on neighboring Bintan Island, one karaoke owner explained in Islamic terms that prostitution is haram (forbidden) but becomes halal (permitted) through tribute to government officials (Ford and Lyons 2008b: 177), thus suggesting that the above logic remains in place. 


\section{Situating the "global"}

James Farrer has argued that-as a global sociological form-the disco should be described as a super-culture rather than a sub-culture. In 1990s Shanghai the disco was primarily a site for youth wishing to engage with global culture (Farrer 1999: 149). At first sight, this would appear to be the case at Ozon as well. The name of the disco, the recognizable beat of the music, the availability of foreign beers and cocktails-at least by name-all suggest a relationship with the "global," and with the various forms of pleasure that organize contemporary forms of consumerism. Much of the vocabulary associated with Ecstasy is in English. Words like tripping, on, enjoy, happy, and refreshing are commonly used and are understood even by Indonesians who do not use Ecstasy or frequent discos on Batam. Titanic, Superman, Mickey Mouse, Honda, and Butterfly are among the most popular kinds of Ecstasy.

In the context of Balinese raves, Beazley (2008: 28-29) notes that her informants use bahasa gado-gado, a mix of Indonesian and English that is the dominant language of contemporary Indonesian youth culture, to be "cool" and take part in a Western world that they consider more advanced and progressive than Indonesia. Furthermore, as in the Chinese nightclubs described by Komlosy (2008: 62), disc jockeys in the main discos in Nagoya play the kinds of songs that they know work well with Ecstasy, while taxi drivers who shuttle people between discos and hotels do the same, as clients and workers are shielded from the unhappy outside world. From this perspective, the local culture of Ecstasy consumption, along with the state and market infrastructure that supports it, appears to offer at least a fleeting engagement with the promises of global capitalism and consumption, thus at least temporarily sustaining Andi's distinction between "fantasy" and "reality."

Yet, as marginal spaces in the context of contemporary processes of globalization, Batam and Ozon should not be understood as strictly belonging to the cosmopolitan culture they mimic. While Batam will never become "Houston," in Ozon, a Long Island Iced Tea is half iced tea, half vodka, ${ }^{4}$ and the Ecstasy is often of uncertain quality. Overdoses are common, because it is often difficult to judge the quality of the drug beforehand. ${ }^{5}$ The music is less "hip" than in Singapore; this bothered Ibrahim in the beginning, but he quickly got used to it because "for Ecstasy all you need is the beat."

The price of entering the disco and of buying Ecstasy makes tripping a form of socioeconomic distinction. Ladies night allows women to enter free of charge several nights a week, but most Indonesian men 
must pay the cover charge, which is around 20,000 rupiah (or 2 United States dollars), about the average salary for a day's work on Batam. Singaporean men, however, are usually not asked to pay as it is expected that they will spend money on the inside. In other words, the gatekeeping principles of Ozon are tied to gendered and national distinctions. Foreign men and Indonesian women do not pay; once inside they are at the center of an economy that will generate more value for the owners of the disco. Singaporean women and Indonesian men do not fit into this world as easily. Once inside, tables, booths, and VIP rooms create a physical environment clearly based on hierarchy. As such, Ozon appears as a site of both social mobility and subordination (e.g., Farrer 2008: 3-4).

In other words, Ozon is an example of what Mary Louise Pratt calls a "contact zone:" "a space in which peoples geographically and historically separated come into contact and establish ongoing relations, usually involving conditions of coercion, radical inequality, and intractable conflict" (Pratt 1992: 6). But, while Pratt's concern with "coercion," "inequality," and "conflict" highlights both the historical origins and economic dimensions of Ozon, she draws our attention away from the role that pleasure plays in relationships of inequality and how "feeling good" is put to work within the political economy of the disco. In other words, inequality is not only temporarily displaced through the consumption of Ecstasy but also reworked in contexts where pleasure is self-consciously produced.

\section{Putting ecstasy to work}

Lidya's Ecstasy has begun to take effect. Like many other women at Ozon, she has taken a Western name that both conceals her identity and self-consciously positions her in a transnational world. Every now and then she leaves her regular spot and circles Ozon searching for a client. She says that she can tell the Singaporeans from the Indonesians by the way they dress. Andi's baggy jeans and Manchester United soccer jersey, for instance, immediately marks him as Singaporean. Sometimes Lidya lingers behind a potential client, but once she is on it becomes much easier to initiate a conversation. She often feels minder-meaning inferior-and malu-meaning approximately shame, embarrassment, or propriety-about approaching clients, and the drug helps her deal with these feelings. Ecstasy, she says, is not only enak (pleasurable) but also "makes me feel berani (brave)."

Freelance prostitutes who work in Ozon use the drug on a regular basis, many of them nearly every night. Unlike brothels or karaoke bars, which are "closed institutions" (Cohen 1993), or prostitutes who 
have a mami, or madam, to negotiate transactions with clients, Lidya and other freelance women must to a greater degree perform to attract clients. It is notable that in Ozon there are no "fish tanks" where clients can pick out women, as there are in most karaoke bars around Batam, suggesting that this is a place where individuals should approach each other freely. Ani, who comes from Central Java, claims that taking Ecstasy "makes everything easier. If I am at the disco and I don't take it, I feel confused and I can't stand the music. I just keep asking myself why I am here. It is also easier to act and dance in a seksi way." Cindi, who comes from the island of Bangka, agrees, saying, "if I have not taken Ecstasy I feel malu if I try to pick up (merayu) a client. I don't know what to say or how to act. It feels strange to touch a client if I am not on."

Lidya lives just down the road from Ozon, where she rents a room with her unemployed boyfriend, Efran, and their baby daughter. During the year or so that I frequented their residence, it quickly became clear that both Lidya and Efran were uncomfortable about her work as a prostitute. While Efran does odd jobs every now and then and occasionally acts as a middleman in the sale of various goods, it is not enough to sustain Lidya and their daughter. As long as Lydia works as a prostitute and Efran cannot act as a "breadwinner," they have decided not to marry. But they hope to exit as soon as they have saved enough capital to return to his home village and open a small shop. Return is in fact the expressed desire of most migrants I encountered on Batam, but as a sustainable act only becomes possible once one has enough capital (modal) to become independent of the insecurities of wage labor. According to Lydia, 20 million rupiah or about 2,000 United States dollars would be enough, which can be compared with the approximately 30 United States dollars she can make if she gets a client for a night.

Within the contemporary Indonesian moral economy of merantau, or circular migration, economic success is thus a general demand, which means that responsibilities toward family members tend to take precendent over religious or other moral ideals. As Sundari, a woman in her early thirties from South Sumatra, put it, referring to her responsibilities toward her children and parents, "whatever work I do, the Lord will be just." In this context, malu, meaning shame, embarrassment, or propriety, keeps unskilled migrants from returning home before they have succeeded, and is arguably the force that drives the Indonesian migratory process (Lindquist 2009). Indeed, when I talked with Lydia and Efran about their hopes for the future, it was clear that the malu that she and Efran both experienced in relation to her work as a prostitute was more manageable than the malu of failure and the impossibility of return and a different form of life. 
For Indonesian women such as Lidya, malu thus becomes an emotional double-bind, as the demands of migration lead many, particularly during the booming crisis economy, to engage in prostitution. Despite the fact that the Islamic regulation of zina (illicit or forbidden sex) applies both to men and women, the contradictory gendered ideals concerning pre- and extramarital sex in Indonesia are widely acknowledged (Murray 1991; Bennett 2005). Often considered a sign of masculinity for men, for women, extramarital sex signifies immorality. The most common Indonesian term for prostitute is wanita tuna sila (WTS), meaning "woman without morals." Of the women-all of them migrants - I talked with in Ozon and on Batam, very few had graduated from high school, making any other form of sustainable employment difficult. Most would agree that extramarital sex is sinful, but frequently legitimized their work as prostitutes in terms of responsibilies toward children and family members, often in the context of an absent or divorced husband.

To be successful, women must learn behaviors that violate Islamic (and Christian) prohibitions against alcohol, drugs, and promiscuity, which are the opposite of those they were taught in childhood and adolescence. Rather than avoid speaking to men they do not know, women must be aggressive and talkative. They must act as though they do not know malu. For freelance prostitutes at Ozon there is a whole repertoire of actions that is learned through practical mimesis and that is facilitated by Ecstasy: learning to dance in a manner that is seksi, or be flirtatious without appearing overly aggressive, or change attitudes depending on the client. The most successful freelance prostitutes are thus not necessarily the ones who are considered most beautiful, but rather, those who have mastered this repertoire. For instance, Cindi, who rarely had problems finding a client, argued that her success was based on her ability to make clients feel comfortable, "like we were boyfriend and girlfriend."

In this context, Ecstasy not only produces feelings of well-being but can also function as a technology for displacing feelings of malu to more easily engage in the libidinal exchange of prostitution (Lindquist 2004). Ecstasy creates the possibility women need to transform themselves into prostitutes and commodify their own bodies. It allows them to forget their malu, by "distancing emotion" (Scheff 1977), and become the kind of woman whom a client will desire, thereby facilitating economic transactions. Judith Butler (1990: 139) argues that "as a strategy of survival within compulsory systems, gender is a performance with clearly punitive consequences." Generally speaking, those who do not perform gender in the correct manner, or who do so randomly, run the risk of being punished by society. In this case, punishment 
entails failing to trade sex, or some form of companionship, for money. As a mediating technology, Ecstasy should thus be understood in relation to the particular environment in which it is consumed and the particular forms of practices that are valued there (e.g., Rose 1999: 52). More specifically, this allows us to move beyond the "pharamacological fallacy," or "the assumption that there is a single, specific drug effect independent of the individual's set or the setting in which the event occurs" (Lenson 1995: 62-63).

Most women claim that the use of Ecstasy makes the actual sexual encounter easier and more pleasurable. This is something that clients and mamis, or madames, also recognize (recall John's quote from the beginning of the article). For instance, Kartika, a woman from West Java, first tried Ecstasy because her mami forced her to. The Singaporean client wanted to book a woman who was taking Ecstasy so that she would be sexually excited, rather than withdrawn and malu. Though Kartika told me that she had promised herself that she would not try Ecstasy, after that first time she claimed that she could not do without it. In other words, an engagement with Ecstasy often appears unavoidable.

Consider Sundari, who asks clients for Ecstasy and then merely pretends to take it, mimicking the movements of those sitting around her. When she goes to the toilet she sells it to a friend or one of the dealers at a greatly reduced price (recall yet another type in John's taxonomy). But Sundari is not successful as a prostitute. She selfconsciously refuses to dress in seksi clothing and remains withdrawn at the disco in order to retain moral dignity. Thus she states: "I am not really a prostitute." During the daytime she works as a petty street trader to further reinforce this identity. But though she can choose not to consume Ecstasy, she still cannot avoid its circulation. It is significant, then, that the only form of impersonation that it is not possible for Sundari to avoid is that of tripping on Ecstasy. However, the economic value that she gains from selling the drug is perhaps less than could be gained from consuming it.

For women who know enough about the particular effects of drugs, it is also possible to transform the relationship with the client and create certain forms of advantages. Reni, another freelance prostitute from West Java, explained that

If I find the client unattractive and he wants me to buy Ecstasy for him, then I always try to get a drug that will not let him get an erection. Of course, this doesn't work on the clients who have been around for a while. But if I really like the guy [starts laughing] then I get the kind that will give him one all night. 
In other words, Ecstasy has different uses within the economy, and pills have various values depending on who uses them, both in terms of consumption and distribution. There is thus a local science of Ecstasy, as different pills affect the body in particular ways, particularly as it is frequently mixed with other drugs such shabu shabu (crystal methylamphetamine).

At around 5 a.m. Ozon closes down. Andi and Sri have already returned home while Lidya has left with a client. Suleiman and Ibrahim stay until the end so that they do not need to hear the early morning Muslim call to prayer. Agus drives them to a restaurant where they have breakfast before they head back to their hotel, where they shower before being taken back to the terminal to catch the ferry back to Singapore. They have been on Batam for about twelve hours and they tell me jokingly, "We don't go to Indonesia; we go to Ozon."

\section{The limits of pleasure}

When Ibrahim and Suleiman first began to travel to Batam in the wake of the economic crisis, they primarily had drugs in mind. "We didn't really plan to go there for the women," Ibrahim told me. "Suleiman and I just headed over to Batam one weekend to see what it was like. We wanted to do Ecstasy because we knew that it was cheaper and safer there than in Singapore." They tried different discos before they eventually settled on Ozon. Ibrahim told me that

In the beginning I was sort of put off by the prostitution. There were all these beautiful women approaching us, but I wasn't interested. I didn't like the idea that I had to pay for sex. But then I started talking to them and then one time this woman asked me if I would buy her some Ecstasy. She told me she wanted thin lady. So I thought, "I might as well."

After having taken Ecstasy with her, Ibrahaim booked the woman for the night. This was repeated as he and Suleiman continued to return to Batam nearly every weekend. "It became easier and finally I didn't even think about it," Ibrahim told me. When I asked him to specify if it was the drugs that had made it easier, he agreed. "Yeah, you forget about things when you are doing Ecstasy and then once you have paid the woman, it feels different the next time, like you already know her. Then it is easier to meet her again." In other words, a relationship has been created that is not strictly sustained by money.

Eventually, Ibrahim and Suleiman initiated more extensive relationships with two women for whom they rented a house on Batam. Within a matter of months, however, they discovered that both of the 
women were continuing to work as prostitutes whenever they returned to Singapore. Since then, they say they have made a conscious effort to stay away from Indonesian women because, as Suleiman put it, "You cannot trust them." Now they just come for the drugs.

Sri, with whom Andi has been having a relationship for almost two years, wants to visit him in Singapore. He sometimes complains that Sri seems to be more interested in his money than she is in him, and he tests her sometimes by not bringing any money, which often makes her angry. Once, he told me, she threw his cell phone out the window when he showed up empty-handed. But still, he might consider marrying her if he ever determines whether or not her feelings for him are true. For the time being, however, he tells me that he wants to maintain a separation between Batam and Singapore. "I want to be able to come here and just enjoy myself."

Andi appears more perceptive than Suleiman or Ibrahim and recognizes his role as a client; he plays with his position, attempting to find some proof of "emotional friendship" (Wolf 2001: 177-179) from Sri. However, their relationship is based on the fact that he can come to Batam and she cannot come to Singapore. In other words, the "freedom" that he gains by coming to Batam depends on the separation of "fantasy" and "reality," a separation that is embedded in the regulation of human mobility between Batam and Singapore.

Researchers who have studied sex tourism from Western countries to Southeast Asia have pointed out that the condition of inequality inherent in the relationship between client and prostitute should ideally (from the client's perspective, in particular) be denied by both parties in the context of their interaction, so it can be presented as primarily a source of pleasure (Bishop and Robinson 1998: 164-165; Kruhse-MountBurton 1995; Oppermann 1999). This denial is necessary because many men are looking not only for sexual satisfaction but also "romance," or most generally, companionship, particularly in "freelance" or "open-ended" (Cohen 1993) prostitution. Outside closed institutions such as brothels, the monetary transaction can more easily be transformed so that neither party presents it as the primary reason for engaging in the relationship.

In contrast, research on contemporary domestic and international sex tourism in China suggests that capitalist expansion, nightlife, and sex are often explicitly linked through casual prostitution or second wives and the development of a transnational business masculinity (Hyde 2007: 107; Shen 2008: 62), or in the case of Japan, corporate masculinity (Allison 1994). In these contexts, it is not necessarily critical that patriarchy and subordination be denied, or that a form of romantic authenticity or reciprocal engagement be produced. 
If nothing else, these different descriptions highlight how the meaning of prostitution varies across time and space, as the relationship between sex, money, and authenticity-and between pleasure and inequality-takes various forms. As in the above description of Western sex tourism, in Ozon there is an explicit engagement with a global culture of techno music, drugs, and sex that celebrates individual agency and the market, but as in the Chinese case, the relationship between subordination and pleasure becomes evident once a relationship is established outside of the disco. For Andi, Ibrahim, and Suleiman it is the movement between the two spheres-from play and pleasure to inequality and subordination - that creates anxieties concerning trust and authenticity.

One of the main reasons that Singaporean men travel to Batam is that drug use and prostitution are both spatially and temporally less regulated there. In my discussions with Singaporean men on Batam who had purchased sex on both sides of the border, most would complain not only about the higher prices in Singapore but also that there were stringent time constraints and that condom use was generally compulsory. Even Indonesian prostitutes who travel to Singapore to work on the streets claimed that the experience of selling sex is different there, because there are fears of police raids and an unspoken rule that condoms should always be used, thus recalling the difference between the Singaporean and Indonesian states that made itself felt during Ecstasy use.

In contrast, on Batam open-ended prostitution is common and presents the possibility of transforming strictly sexual interactions into more extensive relationships. Indeed, many of the Singaporean men I spoke with on Batam-including those discussed in this article-had at one time or another been engaged in long-term relationships with women they had initially met as prostitutes. Most women I knew in fact preferred having a tamu tetap, a regular client or guest. This not only guaranteed a steady source of income but also meant that the emotional labor of prostitution was domesticated, while allowing for the potential of a more sustained-and ethically acceptable-relationship, thus creating the social mobility that merantau demands.

When I talked with Sri once when Andi was away in Singapore, she expressed the hope that they would have children, be married, and move to Singapore at some point. Cindi told me that she dreamed of becoming a housewife in Singapore, while Andi, Ibrahim, Suleiman, and Wen complained that Singaporean women are "too modern" and overly concerned with their professional careers. Other women I knew had children with Singaporean men who supported them, while the men continued to live and work in Singapore. On Tanjung Balai, on 
the nearby island of Karimun, Ford and Lyons (2008a) note similar processes.

In her discussion of the South China border with Hong Kong, a relationship not unlike that between Singapore and Batam, Ong (1999: 154) notes, in relation to the many Hong Kong men who have Chinese mistresses or second families across the border, that "it is one of the many ironies of late capitalism that premodern family forms and female exploitation, which the communist state had largely erased in the cities are being resurrected." The same is true in the relationship between Singapore and Batam. As Andi, Suleiman, and Ibrahim become increasingly marginalized in Singapore through the transformation of the city into a knowledge economy and the intensifying focus on higher education and skilled labor, Batam has offered itself as a space where they all can enjoy more pleasure, power, and respect. "On Batam," one disco manager complained, "Singaporean men can be like kings. Here they give my staff cell phones and have beautiful women. Over there, they are nothing." But the same is also true of men like Wen, who in Singapore would certainly be a part of the middle, and perhaps even upper middle, class, but who then would be caught up in a more intense work cycle and not attain the same level of respect that he does on Batam.

The increasing ease with which Singaporeans can leave the country and engage in various forms of illicit consumption has been matched with an increase in state anxiety concerning citizens' activities abroad. State responses outlined earlier in this article are a case in point. In part, this should be understood in relation to a discourse of "Asian values" that has situated the Singaporean nation and its citizens as a hub of economic efficiency in the changing regional economy (Ong 1999: 201; Wee 1997: 80). In direct juxtaposition to "Western" liberalism and the social ills associated with it (unemployment, divorce, a weak work ethic, and most relevant in this case, drug use), the Singaporean government has aimed to create a new type of citizen. But there has also been an increasing acknowledgment of a politics of inequality. In a National Day Rally speech, for instance, the Singaporean prime minister claimed that the nation could be divided into elite "cosmopolitans" and working-class "heartlanders," the bus drivers and factory workers who populate the city's public housing estates (Chua 2003: 8, Tan 2007: 305).

These processes have led many working-class Singaporean men to experience a particular crisis of masculinity as their decreasing economic power has affected their status as breadwinners within the Singaporean family (cf. Comaroff and Comaroff 2000). Andi, for instance, tells me that “in Singapore women won't even look at me. 
They can see that I don't have a future." As Ford and Lyons (2008a: 63) point out, the increasing tendency for women to "marry up" and men to "marry down" has limited marriage opportunities for collegeeducated women and working-class men with limited education. Furthermore, the difficulties of acquiring a public housing flat for unmarried Singaporeans and the continuing economic demand to care for elderly parents (Göransson 2006: 142-145) place working class men like Andi in a life situation that threatens the shift to a more independent lifestyle beyond parental control, as adolescence in effect is extended.

\section{Ephemeral states}

The consumption of illegal drugs is usually located outside formal models of consumerism, or of a different order; "cocaine capitalism," for instance, has been described as faster, cancerous, and more deadly than conventional capitalism (Lenson 1995: 72). In the Indonesian borderlands, Ecstasy is also productive, facilitating a range of economic transactions, including informal activities such as prostitution, but also a local market for hotels, restaurants, taxis, and other services of the formal economy. Ecstasy is a key element drawing people to Batam and generates revenue that other forms of law enforcement would destroy. In other words, Ecstasy problematizes the distinction between "formal" and "informal," and "legal" and "illegal." Much like video piracy in Nigeria (Larkin 2004), Ecstasy on Batam is both parisitic and constitutive of emergent forms of transnational economies, infrastructure, and social relations.

In his book Opium and Empire, Carl Trocki (1990) has argued that opium was more important than free trade in the economic development of Singapore during the nineteenth and early twentieth century, because it allowed the colonial state to efficiently bind labor to the work place through addiction. From one perspective it is possible to argue that Ecstasy fulfills a similar role on Batam in the context of prostitution, certainly not on the same scale and not necessarily through explicit coercion or physical addiction, but rather through the production of "pleasure" and the temporary transformation of subjectivity among both Singaporean men and Indonesian women.

On Batam, I have argued, Ecstasy creates a zone of pleasure and becomes a means for temporarily easing asymmetrical relations and producing new ones in the contact zone. Ecstasy is the mediating technology for these relationships. Yet neither prostitutes nor clients take the drug merely to facilitate coercive relationships; for some it is a personal experience, for others a means of loosening ambivalence 
around libidinal encounters, and for yet others an object to be sold. What is common across these uses is the fact of engagement with the drug in the globalized cosmopolitan culture that Ozon mimics. Even Sundari, the woman who sold her pill, felt obliged to pretend that she was tripping and experiencing pleasure. In Ozon, where Ecstasy use is more important than drinking or dancing, most people, intentionally or unintentionally, are compelled to engage with the drug, one way or another.

The production of Ozon as a place, and the prevalence of Ecstasy use there, can be understood in relation to a broader world of consumption, and the position of pleasure as the organizing principle in this world (Appadurai 1996: 83). Ozon, it appears, is precisely about engaging in pleasure, and Ecstasy is thereby located at the very center of the structures of consumption that organize local (but also transnational) forms of capitalist desire. The pleasure associated with Ecstasy seems to offer at least a fleeting engagement with the promises of global capitalism, as Honda and Mickey Mouse are connected to techno music and Tiger beer. Yet, a closer look suggests the importance of other forces. Ecstasy allows for the establishment of social relations and the temporary reconfiguration of power relations between Singaporean male clients and Indonesian female prostitutes in a transnational libidinal economy in which pleasure and gendered forms of inequality are interconnected.

But as there are attempts to expand this realm into forms of everyday life, the ephemeral quality of consumption becomes obvious, as do the limits of pleasure. Like Derrida's (1981) reading of Plato's use of the ancient Greek word pharmakon, which can be read as either poison or remedy, Ecstasy cannot be reduced to the one or the other. It is positioned at the center of contemporary forms of capitalism, yet the bubble of pleasure it offers is a fragile one and those who experience it must attend to and confront its limits.

This article describes not only that there are limits to how pleasure functions in relation to inequality, and of the limits of consumerism in relation to more enduring structures of inequality and state power, but also that Ecstasy is functional to this economy yet cannot be reduced to a particular dialectical form. This means that we should take the drug seriously by mapping its circulation and effects ethnographically, expecting the unpredictable, so to speak (Strathern 2000: 286). To many, this is certainly not surprising, but what is more interesting is that an ethnography of Ecstasy use from the margins, offers an alternative way to consider transnational processes that are at the very center of contemporary forms of globalization and the postcolonial nation-state. 


\section{Notes}

Received 11 August 2008; accepted 30 July 2009.

Many people have read and commented on various versions of this article. In particular, I thank Natasha Schull and Jennifer Fishman, who invited me to present the first version at the Annual Meeting of the American Anthropological Association in 2002. I am also grateful to Matthew Amster, Joshua Barker, Tom Boellstorff, Clara Han, Jennifer Mack, Aihwa Ong, Maple Razsa, and Mattias Viktorin, who all read later versions. Finally, I thank Tom Wilson and Jonathan Hill for their comments and support, as well as the journal's two anonymous reviewers who helped me clarify my argument.

Address correspondence to Johan Lindquist, Department of Social Anthropology, Stockholm University, SE -106 91 Stockholm, Sweden. E-mail: johan.lindquist@socant.su.se

1. By "technology" I mean "the problem of choosing the most appropriate means for achieving given goals or ends" (Collier and Ong 2005: 8).

2. In this context, comparisons could be made to cocoa leaves, caffeine, or sugar. See, for instance, Mintz's classic study, Sweetness and Power (1985).

3. The region has, however, been characterized by cultural and economic traffic for centuries. Historically, the Straits of Malacca functioned as a transit area for trade between India and China. Singapore was founded by the English for this reason in 1819 , quickly becoming the dominant entrepot in the region, and binding the contemporary Riau Archipelago, of which Batam is a part, and Peninsular Malaysia to its hinterlands. It was first after decolonialization, in the $1960 \mathrm{~s}$, that a border emerged that regulated the movement of goods and people between Indonesia, Malaysia, and Singapore.

4. The standard recipe for Long Island Iced Tea is equal portions vodka, gin, tripple sec, rum, tequila, and some cola.

5. Since the regime of Ecstasy was established on Batam in the mid-1990s, increasing numbers of people have been admitted to hospital emergency rooms. All of the doctors with whom I spoke reported the same pattern: nearly all those admitted are women coming from clubs where Ecstasy is common. Excessively rapid heart beat and breathing problems are common, as well as feelings of fear and depression as they "come down." Although it is too early to make any definite statements concerning long-term effects, recent clinical studies suggest that the chronic use of Ecstasy impairs visual and verbal memory and that it may affect the ability to reason verbally or sustain attention (Bolla et al. 1998, McCann et al. 1999).

\section{References}

Allison, Anne 1994. Nightwork: Sexuality, Pleasure, and Corporate Masculinity in a Tokyo Hostess Club. Chicago: University of Chicago Press.

Appadurai, Arjun 1996. Modernity at Large. Minneapolis: University of Minnesota Press.

Barker, Joshua 1999. The Tattoo and the Fingerprint: Crime and Security in an Indonesian City. Ph.D. Dissertation, Department of Anthropology, Cornell University.

Bennett, Linda 2005. Women, Islam, and Modernity: Single Women, Sexuality, and Reproductive Health in Contemporary Indonesia. New York: RoutledgeCurzon.

Beazley, Harriot 2008. "I love dugem": Young women's participation in the Indonesian dance party scene. Intersections: Gender and Sexuality in Asia and the Pacific 18. 
Bishop, Ryan and Lilian Robinson 1998. Night Market: Sexual Cultures and the Thai Economic Miracle. New York: Routledge.

Bolla, K. I., U. D. McCann, and G. A. Ricaurte 1998. Memory impairment in abstinent MDMA (“ecstasy") users. Neurology 51: 1532-1537.

Bourgois, Philippe 1995. In Search of Respect: Selling Crack in El Barrio. Cambridge: Cambridge University Press.

Butler, Judith 1990. Gender Trouble: Feminism and the Subversion of Identity. New York: Routledge.

Chua Beng Huat 1995. That Imagined Space: The Nostalgia for the Kampung. In Portraits of Places: History, Community and Identity in Singapore. B. Yeoh and L. Kong, eds. Singapore: Times Editions.

Chua Beng Huat 2003. Life is not Complete Without Shopping: Consumption Culture in Singapore. Singapore: Singapore University Press.

Cohen, Eric 1993. Open-ended Prostitution as a Skilful Game of Luck: Opportunity, Risk and Security among Tourist-oriented Prostitutes in a Bangkok Soi. In Tourism in Southeast Asia. M. Hitchcock, V. King, and M. Parnwell, eds. New York: Routledge.

Collier, Stephen and Aihwa Ong, eds. 2005. Global Assemblages: Technology, Politics, and Ethics as Anthropological Problems. Oxford: Blackwell.

Comaroff, Jean and John Comaroff 2000. Millennial capitalism: First thoughts on a second coming. Public Culture 12(2): 291-343.

Derrida, Jacques 1981. Dissemination. Chicago: University of Chicago Press.

Dirlik, Arif, ed. 1993. What Is a Rim?: Critical Reflections on the Pacific Region Idea. Boulder: Westview Press.

Djaelani Gordon, Joyce and David Djaelani Gordon 2003. Drug Abuse in Indonesia: An Increasing Problem During the Economic Crisis. In The Indonesian Crisis: A Human Development Perspective. A. Ananta, ed. Singapore: Institute of Southeast Asian Studies.

Farrer, James 1999. Disco "super-culture": Consuming foreign sex in the chinese disco. Sexualities 2(2): 147-165.

Farrer, James 2008. Play and power in Chinese nightlife spaces. China: An International Journal 6(1): 1-17.

Field, Andrew 2008. From D.D's to Y.Y. to Park 97 to Muse: Dance club spaces and the construction of class in Shanghai, 1997-2007. China: An International Journal 6(1): $18-43$.

Ford, Michele and Lenore Lyons 2008a. Love, sex and the spaces in-between: Kepri wives and their cross-border husbands. Citizenship Studies 12 (1): 55-72.

Ford, Michele and Lenore Lyons 2008b. Making the Best of What You've Got: Sex Work and Class Mobility in the Riau Islands. In Women and Work in Indonesia. M. Ford and L. Parker, eds. London and New York: Routledge.

Göransson, Kristina 2006. Conflicts and Contracts: Chinese Intergenerational Relations in Modern Singapore. Lund Monographs in Social Anthropology 17.

Hyde, Sandra 2007. Eating Spring Rice: The Cultural Politics of AIDS in Southwest China. Berkeley: University of California Press.

Kruhse-MountBourton, S. 1995. Sex Tourism and Traditional Australian Identity. In International Tourism: Identity and Change. M. Lanfant, J. Allcock, and E. Bruner, eds. Sage: London.

Komlosy, Anouska 2008. Yunnanese sounds: Creativity and alterity in the dance and music scenes of urban Yunnan. China: An International Journal 6(1): 44-68.

Larkin, Brian 2004. Degraded images, distorted sounds. Public Culture 16(2): 289-314.

Lenson, David 1995. On Drugs. Minneapolis: University of Minnesota Press. 
Lindquist, Johan 2004. Veils and Ecstasy: Negotiating Shame in the Indonesian Borderlands. Ethnos 69(4): 487-508.

Lindquist, Johan 2009. The Anxieties of Mobility: Development and Migration in the Indonesian Borderlands. Honolulu: University of Hawai'i Press.

Lyttleton, Chris 2004. Relative pleasures: Drugs, development and modern dependencies in Asia's Golden Triangle. Development and Change 35(5): 909-935.

McCann, U. D., Z. Szabo, U. Scheffel, R. F. Dannals, and G. A. Ricaurte 1999. Cognitive performance in W 3,4-methylenedioxymethamphetamine. Psychopharmacology 143: $417-425$.

Mintz, Sidney 1985. Sweetness and Power: The Place of Sugar in Modern History. New York: Viking.

Murray, Alison 1991. No Money, No Honey: A Study of Street Traders and Prostitutes in Jakarta. Singapore: Oxford University Press.

Ohmae, Kenichi 1995. The End of the Nation State: The Rise of Regional Economies. New York: Free Press.

Ong, Aihwa. 1999. Flexible Citizenship: The Cultural Logics of Transnationality. Durham, NC: Duke University Press.

Oppermann, Martin 1999. Sex tourism. Annals of Tourism Research 26(2): 251-266.

Pratt, Mary Louise 1992. Imperial Eyes: Travel Writing and Transculturation. New York: Routledge.

Rose, Nikolas 1999. Powers of Freedom: Reframing Political Thought. Cambridge: Cambridge University Press.

Rush, James 1990. Opium to Java: Revenue Farming and Chinese Enterprise in Colonial Indonesia, 1860=1910. Ithaca, NY: Cornell University Press.

Scheff, Thomas J. 1977. The distancing of emotion in ritual. Current Anthropology 18(3): 483-505.

Shen, Hsiu-Hua 2008. The purchase of transnational intimacy: Women's bodies, transnational masculine privileges in Chinese economic zones. Asian Studies Review 32(1): 57-75.

Sparke, Matthew, James Sidaway, Tim Bunnell, and Carl Grundy-Warr 2004. Triangulating the borderless world: Geographies of power in the Indonesia-MalaysiaSingapore Growth Triangle. Transactions of the Institute of British Geographers NS 29: 485-498.

Strathern, Marilyn 2000. Afterword: Accountability . . . and Ethnography. In Audit Cultures: Anthropological Studies in Accountability, Ethic, and the Academy. Marilyn Strathern, ed. London: Routledge.

Tan, Kenneth Paul 2007. Singapore's national day rally speech: A site of ideological negotiation. Journal of Contemporary Asia 37(3): 292-308.

Trocki, Carl 1990. Opium and Empire. Ithaca, NY: Cornell University Press.

Trocki, Carl 1999. Opium, Empire and the Global Economy: A Study of the Asian Opium Trade 1750-1950. London: Routledge.

Tsing, Anna 2005. Friction: An Ethnography of Global Connection. Princeton: Princeton University Press.

Vollenweider, Franz X., Alex Gamma, Matthias Liechti, and Theo Huber 1998. Psychological and cardiovascular effects and short-term sequelae of MDMA ("ecstasy") in MDMA-naive healthy volunteers. Neuropsychopharmacology 19(4): 241-251.

Wee, C. J. Wan-Ling 1997. Framing the "new" East Asia: Anti-imperialist discourse and global capitalism. In "The Clash of Civilizations?": Asian Responses, S. Rashid, ed. Dhaka: University Press Limited.

Wolf, Eric 2001. Pathways of Power: Building an Anthropology of the Modern World. Berkeley: University of California Press. 